\title{
Picturebook Adaptations of Aesop Fables: An Analysis of Morrison and Pinkney's Adaptations of Three Classic Tales
}

\section{Vivian Yenika-Agbaw ${ }^{1}$ (D)}

Accepted: 30 November 2020 / Published online: 3 January 2021

(c) The Author(s) 2021

\begin{abstract}
This article examines the reconstruction of human foibles in picturebook adaptations of three popular Aesop's fables: "The Ants and the Grasshopper", "The Lion and the Mouse", and "The Hare and the Tortoise". Adopting adaptation and globalectics perspectives, the author illustrates how social hierarchy is deconstructed in these fables where the authors use anthropomorphic animals to moralize about the human condition. Thus, although the adaptations reiterate lessons from the original source material, they deliberately undermine and/or expand the lessons by integrating sociocultural signifiers that situate Black aesthetics at the core of the narratives. The article examines six picturebook adaptations by award-winning artists, Toni and Slade Morrison, and Jerry Pinkney.
\end{abstract}

Keywords Fables $\cdot$ Adaptation $\cdot$ Cultural diversity $\cdot$ Picturebooks

In the 21st century, the art of reimagining tales in other formats has been normalized. Many times, however, young readers are exposed first to the adapted versions

\begin{abstract}
Vivian Yenika-Agbaw is Professor of Literature \& Literacies at the Pennsylvania State University, University Park, where she teaches undergraduate and graduate courses in children's/ adolescent literature. She is the author of Representing Africa in Children's Books: Old and New Ways of Seeing, author/co-author of over seventy articles and book chapters, co-editor of " A Silence Full of Sound': Children and Deaf Culture in Children's Literature and Other Modes of Representations (under contract at the University Press of Mississippi), co-editor of The Blackwell Companion to Children's Literature (under contract), co-editor of the Journal of Children's Literature (2019-2022), and a former IRSCL board member (2017-2019). She has also reviewed manuscripts for Children's Literature in Education, Children's Literature, The Lion and the Unicorn, and Marvels \& Tales: Journal of Fairy-tale Studies, and serves on the Editorial Board of the Journal of Negro Education, Pedagogy, Culture and Society and the Journal of Adolescent and Adult Literacy.
\end{abstract}

Vivian Yenika-Agbaw

Vxy102@psu.edu

1 Pennsylvania State University, University Park, USA 
of an old tale either in its cinematic format or otherwise before they encounter the original source tale. This practice of rethinking old tales in new ways has tremendous potential to dismantle social hierarchies often accorded to Eurocentric classic tales, disrupting the traditional values they espouse to the reader as universal. It also affords people from underrepresented groups whose voices have been stifled for various reasons in the print world, an opportunity to adapt familiar stories in ways that are consistent with their social realities to assert their socio-cultural identities.

The practice of adapting tales for various reasons thrives even more so today than ever given the easy access to social media platforms and to vanity presses that allow authors to self-publish. Traditional publishers are also publishing more adaptations of classic fairy tales, just like film producers are producing movies based on these same tales; as such, they are expanding the options of narratives from which readers/viewers can choose. For instance, we are all familiar with popular retellings of fairy tales such as Grimm Brothers' (1812) "Rapunzel” (Donna Jo Napoli's Zel (1998) and Disney's Tangled (2010)), and James Halliwell-Phillips' (1886) "The Three Little Pigs" (Jon Scieszka and Lane Smith (1996), The True Story of the Three Little Pigs; Trivizas and Oxenbury's (1993) The Three Little Wolves and the Big Bad Pig-adaptations that emphasize points of view to offer narrative alternatives to otherwise traditional tales with limited interpretative possibilities that take into considerations mainly the psychological wellbeing of the White western child. Other adaptations, such as Pinkney's (2007) Little Red Riding Hood, The Nightingale (2002), The Little Match Girl (1999), and The Talking Eggs (1989) have centered race and class expanding the readership of these tales of European origin however. My aim, therefore, in this article, is to examine adaptations that privilege race and/or class by three African American artists to understand how they make the tales new for the Black American audience, a community within which the authors locate themselves. I focus on three popular fables by Aesop: "The Ants and the Grasshopper", "The Lion and the Mouse", and "The Hare and the Tortoise"-fables many have noted have universal appeal.

The adaptations of interest are written by award-winning children's book author/ illustrator, Jerry Pinkney, and award-winning author, Toni Morrison and her son, Slade Morrison-authors of African descent familiar with the contemporary reality of what it means to be Black in 21st century America. With the understanding that "Aesop was of African origin [and that] his Greek name Aisopos was a version of Aethiop or Ethiopian" (Welsh, 2014, unpaged), it makes sense to seek to understand how contemporary Black authors of African descent have adapted the fables for their American audience.

I examine how the adaptive narrative forms - verbal and visual-which these authors employ might enable readers to better understand the complexity of some of the human foibles that manifest in the new settings attributed to otherwise ancient tales. Teresa Welsh (2014), library science scholar of children's literature notes,

The fables of Aesop thought to be a Greek Slave who lived in Greece about $600 \mathrm{BC}$, have had an enduring influence on children's literature. More than 600 animal fables have been attributed to Aesop and many versions have been 
published as faithful retellings of the ancient morality tales or as more modern adaptations (unpaged).

This article is concerned more but with the latter, primarily to understand how two award-winning authors of African descent have reimagined the fables to address pertinent issues of concerns in the African diaspora. Central to my analysis is the use of adaptation and globalectics perspectives - frameworks that guide my understanding of the six fables that have been reimagined in picturebook formats.

\section{Adaptation and Globalectics Perspectives}

In her much-acclaimed book, A Theory of Adaptation, Linda Hutcheon (2013) contests some literary scholars of the out-dated view they hold about adaptations as inferior. She explains, "Like parodies, adaptations have an overt and defining relationships to prior texts usually revealing called 'sources'. Unlike parodies, however, adaptations usually openly announce this relationship" (p. 3). Announcing the relationship between the source tale and the retelling does not mean that the new version is of inferior quality. Neither does it undermine the intellectual and creative abilities of the author of the newer version. Hutcheon (2013) thus, encourages readers to embrace the new life that is breathed into otherwise old stories for new audiences, arguing further:

Adaptation, like evolution, is a transgenerational phenomenon ... Stories do get retold in different ways in a new material and cultural environments; like genes, they adapt to those new environments by virtue of mutation-in their 'offspring' or their adaptations. And the fittest do more than survive; they flourish (emphasis in the original, p. 32).

Although her focus is primarily on film adaptations of literature, her point is relevant to this study on picturebook adaptations of fables. The picturebook storytelling format repackages brief moralistic stories through the interplay of words and visual sign systems to convey meanings in clever ways. Hutcheon (2013) also shares additional reasons for why artists might elect to adapt stories, some of which include the commercial viability of the story in new modes and formats, and for "personal and political motives" (p. 92).

In an earlier essay, Bortolotti and Hutcheon (2007) express concerns about the consistent denigration of adaptations disputing the "fidelity to the original" (p. 444) discourse. In this way, they do not accept that adapted stories be compared to the source. Rather, these stories should stand as stories in their own merit. Furthermore, they note,

It is obviously important to the understanding of an adaptation as an adaptation that we investigate where it has come from (in order words what biologists would call its phylogeny or evolutionary history). When we shift from 'fidelity' concerns to undertaking this related but different kind of study, new analytic opportunities present themselves (p. 446). 
While I have no desire to delve deeper into this argument, suffice it to say that the crux of my study is to investigate the added narrative elements- verbal and visualthat contribute in transforming Aesop's fables for new audiences across the African diaspora. A nod to the original story acknowledges its existence as source material from another era often associated with a particular region-a narrative in a form that is "no longer adequate" (Bortolotti and Hutcheon, 2007, p. 448) for the twentyfirst century audience. Now the narrative is transformed into a new form, to serve contemporary readers who might continue to grapple with the challenges of being human in an ever-evolving global space and are in need of messages that transcend binary modes, which is typical of the original Aesop fables. Looking at these retold fables from an adaptation perspective enables me to further understand how they have come to survive thousands of years. As posited by adaptation scholar, Glenn Jellenik (2017), "Adaptation and Romanticism were both vital eighteenth century literary reactions, born of divergent responses to the same cultural conditions, different approaches to processing a changing world" (p. 38). This continues to be true in the $21^{\text {st }}$ century as children's book authors and illustrators such as Jerry Pinkney create texts to address the changing socio-cultural landscape and thus, make visible the multifaceted nature of experiences evident across our global space, some of which are specific to Blacks.

Another adaptation scholar, Timothy Corrigan (2017) looks at adaptations in terms of "appropriations". To him, "Appropriations are transformative adaptations that remove parts of one form of text (or even the whole) from their original context and insert them in a different context that dramatically reshapes their meanings" (p. 26). This is exactly what the Morrisons and Pinkney are doing-rethinking the popular fables in a new context to center the human concerns of interest to them. By envisioning the fables for a contemporary audience and perhaps as a stimulus to some societal challenges does not render their adaptations inferior to the original. Rather, they are parallel.

This notion of hierarchy in literature is explored in greater detail by postcolonial scholar, Ngugi wa Thiong'o who theorizes Globalectics as an alternative lens through which scholars can participate in discourses of cultural inclusion, and I do situate adapted tales within this context because several artists, especially those of African descent, who adapt tales, do so for cultural inclusivity. In Globalectics: Theory and the Politics of Knowing, Ngugi (2012) posits that "Reading globalectically . . . is to read a text with the eyes of the world; it is to see the world with the eyes of the text. Such reading should bring into mutual impact and comprehension the local and the global, the here and there, the national and the world" (p. 60). In so doing, we are able to see how cultures connect/intertwine; and how cultural artifacts such as folklore and its variants may emerge from such contacts. We also then recognize that the oral form typically identified with indigenous cultures is NOT less than the written form often associated with western civilization. The oral form is a way of knowing and belonging to local and global communities that transcends how we use the written word to identify with place and spaces, for one does not need to possess only a piece of paper or a laptop to tell a story. The storyteller, as in the case of Aesop, simply creates as per the affordances of his/her surrounding, and the immediacy of an experience and social context. As such, each retelling of the story shifts 
depending on the audience and the matter at hand. In this case, the adaptations of the fables have shifted from their original oral form to a picturebook form that can be read and viewed simultaneously. In essence, each one of us has the potential to be a storyteller. In this way, stories belong to everyone and not only to authors who encode them into print or adapt them into films and other modes.

The human foibles that permeate Aesop's fables, though now presented in picturebook formats are still central in the narratives, only differently. If Globalectics, as Ngugi (2013) posits, "assumes an interconnectedness of time and space in the area of human thought and action" (p. 41), how might these adaptations by these African American artists reveal such interconnectedness? My thinking is that they take what is important to them from the source material and develop new stories that reflect their "personal and/or political" motivations for adapting the fables in the first place. And as Hutcheon (2013) claims, these are legitimate reasons for adapting stories. Thus, these authors' adaptations build on what Aesop might have been trying to accomplish centuries ago in an attempt to remind his audiences of their shared common humanity. In their selection of new settings, perspectives through which the stories are narrated, and implied audiences that maybe local and/or global in scope, the authors' new versions assume this interconnectedness. Their texts therefore "can be read as a mirror of the world" (Ngugi, 2013, p. 42). My analysis of the 6 picturebook adaptations follows next.

\section{Adaptations of Aesop Fables: An Analysis}

\section{Lifestyle Choices and Their Consequences (The Ants and the Grasshopper)—Perry Index 373, Classified in AT-U Index as 280A}

This section opens with an analysis of one of Aesop's well-known fables, “The Ants and the Grasshopper". This source material for subsequent adaptations tells the classic tale of a grasshopper who plays all the time while the ants work and gather food for the winter. When the seasons change, he is stranded and has to live with the consequences of not being diligent. Morrison and Morrison's (2003) Who's Got Game: The Ant or the Grasshopper? is the first in their "Who's Got Game?" series of Aesop's fable adaptations. The title departs from the traditional title preparing readers for debate. The adaptation adopts this question format to lure readers into making decisions as to "who's got game?" Rebecca Ferguson (2011) a reviewer of the series explains: "Game is an ambiguous term, which might be taken to mean courage . . . but which might also mean sheer toughness or the power to win, or the uncanny knowledge that helps us survive the things that befall us" (p. 55). So, basically, who might the reader consider tough enough to survive life's challenges: the hardworking ant or the pleasure seeking/giving grasshopper? The first illustrations that lined the bottom border reveal the ant working. However, when the story opens formally, the comic style illustrations show Foxy G (Grasshopper) and Kid A (Ant) sitting on a bench at a park: "They rumped each day till the sun's last ray and didn't stop till dark" (unpaged). They are portrayed as good friends who hang out often until Kid A realizes that the "days [were] getting short" and soon the season would change. 
Foxy G continues to play his music through the winter season: "Still out in the park .. . He wanted to finish one more tune before the coming night" but couldn't" for it was too cold. "Battling shame, he left the park. There was nothing else to do but swallow his pride and drag his wings back to the neighborhood" (unpaged). Kid A would not take him; rather, he reminded Foxy $\mathrm{G}$ of his poor judgement. There is an ongoing dialogue between the friends reminding the other of their responsibilities. For Kid A: planning ahead is important. To Foxy G, music is also important. He pleads his case earnestly, "I quenched your thirst and fed your soul, you can't spare me a doughnut hole? . . . You loved my music so respect me too! How can you say I never worked a day?" To these pleas, Kid A retorts, "You should have known/what tomorrow would bring/Then you wouldn't be begging for anything . . . /WHERE'S YOUR HEAD?" The story ends with Foxy G trapped in the snow. The end pages invite readers to reflect on what just happened, with an illustration of a snow globe containing Kid A's house and Foxy G retreating from the house, and the accompanying question: "WHO'S GOT GAME?" This is followed by a double page spread of an illustration of snowflakes and of a child insect holding the globe and dragging another insect on the snow. She/he seems perplexed by the snow globe, leading to Ferguson's conclusion of the child being a "reflective participant" (p. 59) in the story. If we agree that double page spreads compel the reader to pause and contemplate the events in the illustrations as Nodelman and Reimer (2003) posit, then it is easy to infer that this is a significant moment in the story.

Ferguson (2011) remarks further that, "Toni Morrison has commented that as a child, her son Slade had disliked stories that carried an obvious warning or moral" (p. 55). Citing Capriccioso, she added, "they [morals] were like doors slammed in your face" (p. 55). Slade “'didn't understand why people always jumped on the grasshopper"' (p. 55). This is partly the reason why Toni and Slade embarked on the project.

The "streetwise language" (Ferguson, p. 56) adds to its appeal locating the story within a specific community of readers and as such situates the Morrisons' version within a contemporary urban Black American setting over the traditional source material that has informed our collective consciousness for centuries. Moreover, as Ferguson rightly observes of the stories within the "Who's Got Game" series, the "interplay of notes and tones and connoted meanings serves to highlight the dynamic power of the stories as they might be delivered in an oral, dramatic, or shared interrogative context" (p. 57). This centers orality often relegated to the periphery as a legitimate form of literature, as Ngugi (2012) professes.

While the Morrisons emphasize the relationship between one ant and one grasshopper, Pinkney's (2015) The Grasshopper and the Ants focuses on one grasshopper and several ants though in reverse order of the source material. Like the Morrisons', it also rethinks the moral revising it by bestowing the queen ant a generous spirit that enables her to invite the grasshopper for tea at the end of the story. The grasshopper is appreciative of this act of kindness and entertains his hostess and the other ants. Pinkney explains in the backmatter:

The opportunity to convey music through visual art was too rich and exciting to resist ... It stirred my imagination to envision the winged grasshopper as 
a one-man band, and to invent a simple, lyrical text with the hint of a chorus. The musical element of the fable also relates to the theme of harmony that, in this version, pulls the story together in the end. Traditionally, the tale does not elaborate on what happens to the grasshopper as a result of his lack of planning; in my story, the ants have learned to generously share what they've worked for, and in the scene on the final endpaper, it's apparent that the grasshopper has learned to plan better for the next year (unpaged).

Thus, like the Morrisons, his verbal text locates the orality of fables within a literary tradition that has always privileged the printed word; the visual texts confirm the events. The grasshopper that is supposed to be left on the periphery for not following the basic rules of survival is given another chance to redeem itself and brought back to the center. “'A cup of tea?' asked Queen Ant. 'How kind of you', said the Grasshopper" (unpaged). He accepts and in turn entertains the ants. The double page spread establishes the characters as equal partners in this negotiation of truce. The subsequent double page spread shows him entertaining the ants, and the final single page image is of him and the queen having tea. This ending departs from the source material whose moral, "There's time for work and a time for play" (see the original fable: http://www.read.gov/aesop/052.html) conveys an overt disapproval of the grasshopper's lack of foresight. It also differs from the Morrisons' that remains open-ended and so reflects Pinkney's ideology of compromise.

\section{Negotiating Friendship Through Acts of Kindness ("The Lion and the Mouse" 150 Perry Index, Unclassified in AT-U Index)}

This next fable, classified as Type 150 within the Perry index https://fablesofaesop. com/the-lion-and-the-mouse.html but unclassified within the Aarne ThompsonUther index best exemplifies this category. The moral stated in the source material is "A kindness is never wasted (see text: http://www.read.gov/aesop/007.html). Morrison and Morrison (2003), and Pinkney's (2009) retellings interpret the moral differently: kindness that fosters an inflated ego (Morrison and Morrison), and kindness that translates into genuine friendship (Pinkney). Between the two, Morrison and Morrison's (2003) Who's Got Game: The Lion or the Mouse? is the more disturbing as it conflates what seems like kindness initially with bullying acts. The idea of physical size playing a contributing role to bullying is discredited early. A bully is a bully regardless of physical size and prowess.

The lion is introduced as a bully, "strutting over the savannah" asserting his dominance "I AM THE KING ALL OVER THE LAND. I DO WHAT I LIKE. I DO WHAT I CAN." But six pages into the story, he quickly learns that even a King needs help, which he gets from a mouse the most unlikely animal he would have imagined. None of the other animals is willing to pull the thorn off his paws to relieve him of the excruciating pain; only the mouse who is "too small [and] too weak". For this kind act, Lion promises to be Mouse's friend "forever", but events take a different turn, as Mouse's ego becomes inflated: "I'M NO LONGER A MOUSE, I'M A LION NOW" (unpaged). As such, he turns into a bully. The story ends with Lion pondering Mouse's new attitude retrospectively: "Is he who 
wants to be a bully just scared to be himself?" (Unpaged). With this timely message embedded in Morrison and Morrison's (2003) retelling, the immediacy of Pascal Lemaitre's comic illustrations grabs the reader's attention complementing the rhymes and adding humor to the story. The ending is open-ended for readers to resolve however they see fit: who/what is a bully. The Mouse remains seated on the Lion's throne looking petrified at a small insect on the floor. So, while it is a story about kindness and friendship, it is also a cautionary tale about how perceived power can blind one to his/her bullying tendencies. But when the authors pose the question: "Who's Got Game?", they ask readers to contemplate the characterization and events, and to ponder how the lion, and subsequently the mouse shifts from the center/periphery and periphery/center in the story. Thus, a marginalized person is capable of becoming a bully similarly like someone at the center.

Pinkney's (2009), The Lion and the Mouse, a picturebook retelling of the same fable published six years later explores the relationship between Lion and Mouse, as well as humans and animals. Told primarily through visual images in double page spreads, the reader is drawn into the animal world where Lion is King. Unlike the Morrison's, the plot follows the traditional tale of Mouse in danger of being eaten by the Lion; however, Lion releases her after a multicultural dialogue captured in this manner: "GRRR" (LION) and "Squeak" (Mouse). The reader can simply assume that the two animals came into an understanding from this brief conversation and after staring at each other suspiciously for a while as the illustrations convey.

Pinkney's images emphasize the physical sizes of the two partners depicting the lion across several double page spreads and the mouse occupying just a small portion of the page and mostly as an object in the lion's paws. In this way, he heightens the tension. Once the mouse is released, she runs to her nest of mice as the lion watches. No sooner after that does the reader encounter two faceless poachers setting up a snare that eventually traps the mighty lion. The mouse eats her way through the twine and releases the lion and all is well. In the "Artist's Note", Pinkney observes,

this is the tale of a mouse who accidentally disturbs a lion from his rest, and the lion who makes a life-changing decision to release his prey. When the mouse remembers her debt, she frees the lion from a poacher's trap. For me, this story offers far more than a simple moral of how the meek can trump the mighty. . . As a child I was inspired to see the majestic king of the jungle saved by the determination and hard work of a humble rodent; as an adult I've come to appreciate how both animals are equally large at heart; the courageous mouse, and the lion who must rise above his beastly nature to set his small prey free. It was gratifying, then to place these two spirited creatures headto-head on this book's jacket, each commanding powerful space and presence (unpaged).

From a globalectics perspective, neither of the creatures is at the periphery as is evidenced in the illustrations on the front/back jacket covers, even though the story starts off by centering Lion as the superior animal. They need each other to survive in this jungle and as such are constructed as equals with the image of Mouse blown up to scale. 
The two adaptations dislocate the center, Lion, by bringing Mouse, a character typically identified with the periphery within the animal kingdom to the center, a basic tenet of Ngugi's (2012) Globaletics. However, in Morrison and Morrison (2003), the mouse now at the center reconstructs the same hierarchical power structure that had disenfranchised it all its life. The authors use this to speculate on why bullies fight to hold onto power, a point they make throughout Who's Got Game: The Lion or the Mouse?. Pinkney's adaptation concludes by centering both the lion and the mouse, as is evidenced in the last sets of the illustrations. In one illustration where the lion is free from the snare, Lion is depicted looking down in disbelief at the small Mouse that has just saved him.

The last illustration readers encounter depicts Mouse as larger than the other mice, an image that is positioned at the center of the full page. Lion no longer features in their world as a threat, for that part of the kingdom is what Ngugi (2012) would refer to as Mouse's "here" and other parts where she encounters other animals her "there". Mouse is now part of the larger animal network where animals are positioned to work collaboratively to make the environment safe especially from human beings rather than prey on each other. Quoting Ngugi, Duncan McEachern Yoon (2013) postulates,

In a network there is no one center, all are points balanced and related to one another by the principle of giving and receiving' (Ngugi 61). Ngugi's rhizomatic network works to dismantle the hierarchy of center and periphery through a relational give and receive. The tangled network of a rhizome allows for entities to make connections with the effect of an overall mutual benefit, which lies outside of an enforced dynamic of power (unpaged).

This is what happens in the two adaptations of "The Lion and the Mouse" fable.

\section{Perspectives on Success: Who Succeeds and How? ("The Tortoise and the Hare"- 226 Perry Index; 275A AT-U Index)}

We live in a competitive world is the essence of Morrison and Morrison (2010), and Pinkney's (2015) adaptations of the third Aesop's fable examined here, although each recognizes the unfair nature of competition given our varied talents vis 'a vis what is rewarded as success.

Morrison and Morrison (2010) see success as various depending on one's unique talent, skill sets, and perspective as is evident in their Who's Got Game: The Tortoise and Hare? The version deviates quite a bit from the source material with a moral that states: "It's not the race. It's not who wins. It's when the runners become good friends." In this way, it echoes Pinkney's message of cultivating friendship regardless of the outcome of the race. While Pinkney sets his in "the American Southwest because it's a natural habitat for various tortoise and hare species" (unpaged), Morrison and Morrison's setting seem generic. But their characters are developed further in the verbal text with identifiable names and gifts. Jimi Hare is a gifted athlete "who ran faster than anybody, everybody, everywhere [and] didn't know why his legs were made that way." Jamey Tortoise is gifted too. He is "smarter than 
anybody, everybody, everywhere [and] didn't know why his mind was so fast or his intelligence so high" (unpaged). For being gifted both characters are shunned and so each is isolated until the media announces the contest. In this version, though Jimi wins, the authors revise the ending so that both characters win in some way-hence the idea of putting success into perspective. Artistic styles also differ.

For Pinkney (2013), there will always be some kind of competition but success involves endurance, persistence, and determination with an eye on the price regardless of natural ability that may give some an unfair advantage. In his The Tortoise and the Hare, the hare is known as the "quickest" and the tortoise as the "s. . .l. . .o. . .w. . .e. . .s. . .t". The hare loses nonetheless partly because of arrogance and a lack of self-discipline. Pinkney's adaptation is the closest to the source material. However, his visual narrative integrates few words that serve like sound bites of the lesson he would like the readers to get: "SLOW AND STEADY WINS THE RACE!" metaphorically and in reality, within the social world he constructs in his visual texts. The last illustration in the book reiterates the point about the essence of winning and/or losing a race, for Hare recognizes that Tortoise won fair and square, even though he had an unfair advantage-he was "slow" but "steady". By losing Hare gains a new perspective on what success entails. In the backmatter Pinkney notes,

I remember hearing 'The Tortoise and the Hare' when I was a child, not just as one of Aesop's classic fables but also as one of the tales of Uncle Remus. . . . I have always been intrigued by the fact that this fixture of my own childhood lived also in the imaginations of colonial enslaved people. 'Slow and steady wins the race' was particularly meaningful in my youth, since I often struggled in school because of dyslexia, but the moral rings truer ever today. As the pace of our lives continues to speed up, many yearn for a less hurried approach to life. The tortoise proves that it can be wise to have a goal, but one should relish the process of getting there. The handling of the text in this version echoes that message ... But I wanted the hare to teach something, too: Winning isn't everything. He surprises his friends by not being the sore loser they night expect. Competitors can also be teammates and friends. (unpaged).

By graciously recognizing Tortoise's win Hare not only conveys the spirit of good sportsmanship, but also makes a new friend. This act of goodwill thus centers them both pulling Tortoise from the periphery with which he had been identified in their fictive community. Pinkney's moral "Slow and Steady wins the race" are the only words that appear in this picturebook that visually narrates the story in several double paged spreads (see Aesop's Fables as translated by Vernon Jones for the same moral-https:// www.pitt.edu/ dash/type0275.html\#jones). Throughout, Hare is portrayed as an entitled athlete given his natural skill set as a fast runner. He is favored to win. All the animals are therefore surprised when Tortoise actually wins. More so, they are impressed to see Hare concede and as such "dissolve[s]" the "[c]enter and periphery . . . as hierarchical categories; [so] they become merely situational designations that allow for a leveling of the sociocultural playing field" (Yoon, 2013 unpaged). This way, "The Tortoise and the Hare" as in the case of Morrison and Morrison's adaptation, is no longer a tale that positions characters in binaries of loser/winner, for both characters experience 
different kinds of growth: Hare, recognizing his fallibility, and Tortoise, appreciating his determination and endurance. They become friends.

The two adaptations of this particular fable alter the title, placing Tortoise as the lead character and Hare as the supporting character to foreshadow the outcome of the race and thus prepare readers for a different way of thinking. Aesop's original title reads "The Hare and the Tortoise" with a stated moral of: "The race is not always to the swift" (see the original fable: http://www.read.gov/aesop/025.html). Each adaptation revises this moral to some degree for the contemporary reader, and to perhaps reflect authorial intent and ideology.

\section{Discussion}

For Rebecca Ferguson (2011) the Morrisons and Lemaitre's adaptations "draw upon different source materials and mythic associations; and . . . are directed to the interest of the contemporary child reader in such a manner so as to sustain inquiry and to provoke interrogation" (p. 54). Pinkney's likewise, though not necessarily for the same reason as the Morrisons. While they also target contemporary child readers, the adaptations vary in their intent with The Grasshopper and the Ants teasing notions of a second chance; The Lion and the Mouse, drawing attention to environmental concerns and the need to collaborate, and The Tortoise and the Hare reminding readers to be self-disciplined, as it affirms the potential to succeed even those with unfair advantages. Morrison and Morrison's are teen centered, deliberately provocative and are consistently informed by the African American vernacular tradition. Ferguson (2011) observes,

An assessment of the interrogative and graphic power of the books ["Who's Got Game"] entails giving close attention to their use of idiom and the vernacular, to the complex interplay between word and visual medium, to the distinctive settings in which the stories are placed, and to the cultural references which form a significant part of their communicative framework (p. 55).

This can also be said of all the adaptations. Each author taps from the source material and produces something new for a new audience. Close reading may reveal different ideologies that inform these adaptations, but as Hutcheon (2013) reminds us tales will continue to "mutate". However, "the fittest do more than survive; they flourish" (p. 32), and artists, publishers, educators and readers contribute to the flourishment of stories regardless of their cultural origin. In this case, the Morrisons, and Pinkney are helping the fables to flourish inviting the Black community into the ongoing dialogue in a meaningful and relevant way.

\section{Conclusion}

Ngugi (2013) observes, "The traveler of old, on foot, boat, or horseback, was a carrier of tales from location to another. The stories would of course be retold, and acquire local color depending on the teller of the tale. The tale was not 
confined to the national homeland or region" (p. 42). Morrison and Morrison, and Pinkney's adaptations of popular Aesop fables signify this notion. They are modern "travelers" whose footprints bring along Black cultural aesthetics, histories, geographies, and consciousness; and whose picturebook adaptations are also indicative of their physical, spiritual, artistic, and metaphorical journeys of naming the "self".

In adapting the fables for an American and global audience, these artists also situate their narratives within local and global discourses of capitalism and imperialism - the starving artist who makes unwise decisions, the fastest athlete whose arrogance costs him fame, the slowest person whose endurance yields fruits, and the bully, whose insecurity is unmasked. These African American artists - storytellers - have added a local color that makes the fables uniquely theirs while still paying homage to the original source material. The "mutation" is visible. Through the adaptations, readers can begin to understand that what was construed as vices and/or virtues in the "ancient" fables from Greece a long time ago is now open for debate. They can also learn to accept that the "Other" cannot continuously be punished for not conforming to a world view that oppresses. It is a new world order today!

Open Access This article is licensed under a Creative Commons Attribution 4.0 International License, which permits use, sharing, adaptation, distribution and reproduction in any medium or format, as long as you give appropriate credit to the original author(s) and the source, provide a link to the Creative Commons licence, and indicate if changes were made. The images or other third party material in this article are included in the article's Creative Commons licence, unless indicated otherwise in a credit line to the material. If material is not included in the article's Creative Commons licence and your intended use is not permitted by statutory regulation or exceeds the permitted use, you will need to obtain permission directly from the copyright holder. To view a copy of this licence, visit http://creativecommons.org/licen ses/by/4.0/.

\section{References}

Bortolotti, G., and Hutcheon, L. (2007). On the Origin of Adaptations: Rethinking Fidelity Discourse and "Success" - Biologically. New Literary History, 38(3), 443-458. http://www.longw ood.edu/staff/miskecjm/357bortolotti.pdf. Accessed July 10, 2018.

Corrigan, T. (2017). Defining Adaptation. In Thomas Leitch (Ed.), The Oxford Handbook of Adaptations (pp. 23-35). Oxford, UK: Oxford University Press.

Ferguson, R. (2011). Of Snakes and Men: Toni and Slade Morrison's and Pascal Lemaitre's Adaptations of Aesop in Who's Got Game? Mellus, 36(2), 53-70. https://www-jstor-org.ezaccess. libraries.psu.edu/stable/pdf/23035280.pdf?refreqid=excelsior\%3A8a9036cd22d4995724555e8 807a9eef3. Accessed July 19, 2018.

Hutcheon, L. (2013). A Theory of Adaptation, 2nd ed. London, UK: Routledge.

Jellenik, G. (2017). On the Origin of Adaptation, As Such: The Birth of a Simple Abstraction. In Thomas Leitch (Ed.), The Oxford Handbook of Adaptations (pp. 36-52). Oxford, UK: Oxford University Press.

Ngugi wa Thiong'o. (2013). A Globalectical Imagination. http://www.globalsouthproject.corne 11.edu/uploads/2/8/6/4/28645597/a_globalectical_imagination.pdf. Accessed July 11, 2018.

Ngugi wa Thiong'o. (2012). Globalectics: Theory and the Politics of Knowing. New York: Columbia University Press. 
Nodelman, P., and Reimer, M. (2003). The Pleasures of Children's Literature, 3rd ed. Boston: Allyn and Bacon.

The Aesop for Children with Original pictures from Milo Winter. Washington DC: Library of Congress. http://read.gov/aesop/. Accessed July 9, 2018.

Yoon, D. (2013). World Literature and the Postcolonial: Ngugi's Globalectics and Glissant's Poetics. http://www.globalsouthproject.cornell.edu/world-literature-and-the-postcolonial-ngugirsquo s-globalectics-and-glissantrsquos-poetics.html. Accessed July 18, 2018.

Welsh, T. (2014). Aesop Through the Ages: An Examination of Aesop's Fables in the de Grummond Children's Literature Collection. Mississippi Libraries, 77(1), 5-8.

\section{Children's Book Cited}

Morrison, T. and Morrison, S. (2014). Who's Got Game?: The Lion and the Mouse. Illustrated by Pascal Lemaitre. New York: Simon and Schuster.

Morrison, T. and Morrison, S. (2003). Who's Got Game?: The Ant and the Grasshopper? Illustrated by Pascal Lemaitre. New York, NY: Scribner. First Edition

Morrison, T. and Morrison, S. (2010). Who's Got Game?: The Tortoise and the Hare. Illustrated by Joe Cepeda. New York, NY: Simon and Schuster.

Pinkney, J. (2015). The Grasshopper and the Ants. New York, NY: Little Brown and Company.

Pinkney, J. (2013). The Tortoise and the Hare. New York, NY: Little Brown and Company.

Pinkney, J. (2009). The Lion and the Mouse. New York, NY: Little Brown and Company.

Publisher's Note Springer Nature remains neutral with regard to jurisdictional claims in published maps and institutional affiliations. 